\title{
Pemanfaatan ovitrap dalam pengukuran populasi Aedes sp. dan penentuan kondisi rumah
}

\author{
Utilization of ovitraps in Aedes sp. population measurements \\ and determination of house condition
}

\author{
Lisa Hidayati' ${ }^{1}$, Upik Kesumawati Hadi², Susi Soviana² \\ ${ }^{1}$ Program Studi Analis Kesehatan, Politeknik Piksi Ganesha Bandung \\ Jalan Gatot Subroto No. 301, Bandung 40274 \\ ${ }^{2}$ Departemen Ilmu Penyakit Hewan dan Kesehatan Masyarakat Veteriner, \\ Fakultas Kedokteran Hewan, Institut Pertanian Bogor \\ Jalan Agatis Kampus IPB Dramaga, Bogor 16680
}

(diterima Oktober 2016, disetujui November 2017)

\begin{abstract}
ABSTRAK
Kejadian demam berdarah dengue (DBD) masih menjadi masalah kesehatan masyarakat di Indonesia. Pengamatan selama kurun waktu 20 sampai 25 tahun sejak awal ditemukan kasus DBD menyatakan bahwa angka kejadian luar biasa DBD mengalami peningkatan setiap lima tahun. Tujuan dari penelitian ini adalah 1) mempelajari keanekaragaman nyamuk Aedes di kota Sukabumi, 2) mengukur populasi Aedes sp. berdasarkan jumlah telur dan indeks ovitrap, dan 3) mengetahui hubungan indeks ovitrap dengan kondisi rumah. Telur Aedes sp. dikumpulkan dari 14 kelurahan di Kota Sukabumi yang memiliki angka insiden tertinggi, mulai dari bulan Mei 2015 hingga Agustus 2015. Pengumpulan telur dilakukan dengan cara memasang perangkap telur (ovitrap) sebanyak 230 buah di 115 rumah (di dalam dan di luar rumah). Hasil pengumpulan ovitrap menunjukan jumlah telur yang diperoleh dari ovitrap di dalam rumah 3 kali lebih banyak dibandingkan dengan telur dari ovitrap di luar rumah (1307 banding 429). Nyamuk Ae. aegypti ditemukan pada ovitrap di dalam rumah dan Ae. albopictus pada ovitrap di luar rumah. Indeks ovitrap di dalam rumah mencapai $60 \%$, atau 1,6 kali lebih banyak dibandingkan dengan indeks ovitrap di luar rumah (37\%). Rumah dengan ventilasi dan sanitasi buruk berisiko 3,09 kali meningkatkan angka indeks ovitrap. Hasil penelitian ini dapat digunakan sebagai informasi dasar bagi masyarakat untuk meningkatkan kebersihan lingkungan melalui pengurangan tempat perindukan nyamuk sehingga menurunkan kejadian DBD.
\end{abstract}

Kata kunci: ovitrap, kondisi rumah, telur Aedes spp.

\begin{abstract}
The incidence of dengue hemorrhagic fever (DHF) is still a public health problem in Indonesia. Observations over a period of 20 to 25 years since the beginning of the discovering of the disease, has show the increase of the diseases incidence every five years. The purpose of this study are 1) study the diversity of Aedes's mosquitoes in Sukabumi City, 2) measure the Aedes population based on the number of eggs and ovitrap index, and 3) to know the correlation between ovitrap index and house condition. Aedes eggs were collected from 14 villages in Sukabumi City that has the highest incidence rate, started from May 2015 until August 2015. Collecting eggs is done by setting a trap eggs (ovitrap) as many as 230 pieces in 115 homes (indoor and outdoor). The results showed that Ae. aegypti were found inside houses and Ae. albopictus were outside houses. The number of eggs collected from ovitrap inside the houses were three times more than those collected from outside. Ovitrap index inside houses was $60 \%$, or 1.6 times more than the ovitrap index outside the houses
\end{abstract}


$(37 \%)$ in 14 villages in Sukabumi. Houses with poor ventilation and sanitation increased the risk 3.09 times of number of ovitrap index. The results of this study could be use as basic information for the communities to improved environment hygiene through reduced mosquito breeding sites, thus degraded the incidence of dengue.

Key words: Aedes spp eggs, house condition, ovitrap

\section{PENDAHULUAN}

Demam berdarah dengue (DBD) adalah penyakit yang disebabkan oleh virus dari Famili Flaviridae yang ditularkan oleh serangga. Serangga yang diketahui menjadi vektor utama adalah Aedes aegypti Linnaeus dan Aedes albopictus (Skuse) sebagai vektor sekunder (Gubbler 1998). Kejadian DBD masih menjadi masalah kesehatan masyarakat di Indonesia. Pengamatan yang dilakukan oleh Dinkes Provinsi Jawa Barat selama kurun waktu 20 sampai 25 tahun sejak awal ditemukan kasus DBD menyatakan bahwa angka kejadian luar biasa DBD mengalami peningkatan setiap lima tahun. Kota Sukabumi menduduki peringkat pertama se-Provinsi Jawa Barat untuk kasus DBD dari tahun 2010-2014 setelah kota Bandung dan Cimahi (Dinkes Provinsi Jawa Barat 2015). Berdasarkan jumlah kasus dan nilai IR (incidence rate), penderita DBD di Kota Sukabumi dari tahun 2011-2014 masih tinggi walaupun telah terjadi penurunan kasus. Pada tahun 2011 terdapat 531 kasus $(I R=149,12), 2012$ tercatat penderita DBD sebanyak 922 kasus (IR = 252,88), 597 kasus (IR $=174,52)$ pada tahun 2013, dan sekitar 801 kasus $(\mathrm{IR}=254,28)$ di tahun 2014 (Dinas Kesehatan Provinsi Jawa Barat 2015; DKK Sukabumi 2014).

Survei entomologi adalah komponen penting dan langkah awal dalam menentukan program pengendalian vektor yang lebih efektif. Survei entomologi banyak digunakan untuk mendeteksi perubahan kepadatan dan distribusi vektor yang bermanfaat dalam pencegahan dan pengendalian vektor. Selain survei jentik yang merupakan survei entomologi yang terdiri atas indeks house $(\mathrm{HI})$, indeks breteau (BI), dan indeks container (HI), indeks ovitrap (OI) dapat digunakan untuk menambah informasi aktifitas bertelur nyamuk betina dewasa di dalam dan di luar rumah (Norzahira et al. 2011). Indeks ovitrap digunakan untuk mendeteksi Ae aegypti betina gravid, Ae. albopictus betina gravid dan genus Aedes yang lain (Mackay et al. 2013). Apabila terdapat telur nyamuk, bisa disimpulkan adanya betina gravid yang kemungkinan bisa menjadi vektor DBD. Walaupun demikian, ovitrap tidak akan efektif lagi jika ditempatkan lebih dari 1 minggu karena bisa menjadi tempat perindukan nyamuk baru (Barrera et al. 2013). Selain itu, indeks ovitrap dapat menjadi alternatif teknik yang digunakan dalam pengendalian vektor selain survei jentik karena metode ovitrap juga dapat mendeteksi nyamuk dari tempat perindukan yang tidak terjangkau dari area di sekitarnya (Beech et al. 2009; de Resende et al. 2013)

Aedes sp. akan bertelur setelah menghisap darah dan jumlah telur rata-rata 100 butir setiap kali bertelur. Stadium telur Ae. aegypti tahan terhadap kering, dapat bertahan selama berbulan-bulan bahkan lebih dari satu tahun (Christophers 1960). Telur diletakan satu persatu pada dinding kontainer dekat dengan permukaan air. Telur bewarna gelap, umumnya menetas secara bersamaan menjadi larva pada suhu optimum $\left(25-30^{\circ} \mathrm{C}\right)$ di dalam air. Larva Aedes sp. hidup pada air yang jernih dan tenang serta mengandung bahan organik. Larva akan berkembang menjadi kepompong (pupa) dalam waktu 5-6 hari, sedangkan pada suhu di bawah $10{ }^{\circ} \mathrm{C}$ larva akan mati. Setelah 5-6 hari larva Aedes sp. akan berubah menjadi pupa. Temperatur optimum untuk perkembangan berkisar $27-32{ }^{\circ} \mathrm{C}$. Pada temperatur tersebut pupa jantan membutuhkan waktu berkembang ratarata 1,9 hari, sedangkan yang betina akan membutuhkan waktu rata-rata 2,5 hari. Setelah 1-2 hari pupa berubah menjadi nyamuk dewasa. (Gubbler 1998; Hadi \& Koesharto 2006; Sukowati 2010).

Beberapa penelitian menyebutkan bahwa vektor utama DBD, yaitu Ae aegypti tidak hanya ditemukan di dalam rumah, tetapi juga ditemukan di luar rumah dengan kepadatan cukup tinggi (Wan-Norafikah et al. 2011; 2012, Mohiddin et al. 2015). Oleh sebab itu, perlu dipastikan dan diketahui persebaran Aedes di dalam dan luar rumah melalui angka indeks ovitrap di Kota Sukabumi. Berdasarkan uraian di atas, 
tujuan dari penelitian ini adalah 1) mempelajari keanekaragaman nyamuk Aedes di kota Sukabumi, 2) mengukur populasi Aedes sp. berdasarkan jumlah telur dan indeks ovitrap, dan 3) mengetahui hubungan indeks ovitrap dengan kondisi rumah di Kota Sukabumi sehingga membantu pembuat kebijakan dan masyarakat untuk memberantas dan mengendalikan vektor DBD yang efektif dan efisien.

\section{BAHAN DAN METODE}

\section{Lokasi penelitian}

Pengambilan sampel telur Aedes dilakukan pada bulan Mei hingga Agustus 2015. Telur nyamuk dikumpulkan dari 7 kecamatan dan tiap kecamatan dipilih 2 kelurahan berdasarkan incidence rate DBD tertinggi, yaitu Kecamatan Cikole (Kelurahan Selabatu dan Cisarua), Kecamatan Gunung Puyuh (Kelurahan Kramat dan Gunung Puyuh), Kecamatan Warudoyong (Kelurahan Benteng dan Dayeuh Luhur), Kecamatan Citamiang (Kelurahan Nanggeleng dan
Citamiang), Kecamatan Cibeureum (Kelurahan Cibeureum Hilir dan Babakan), Kecamatan Baros (Kelurahan Baros dan Sudajaya Hilir), dan Kecamatan Lembur Situ (Kelurahan Lembur Situ dan Cikundul) (Gambar 1).

\section{Pengambilan sampel telur}

Pengumpulan telur dilakukan dengan cara memasang perangkap telur (ovitrap). Ovitrap dibuat dari gelas plastik yang dicat hitam bagian luarnya. Pada saat pemasangan, gelas diisi sepertiganya dengan air dan kertas saring diletakan di sekeliling dinding permukaan dalam gelas untuk tempat melekatnya telur nyamuk. Ovitrap diletakkan di dalam (terutama di tempat gelap dan lembab yang merupakan tempat persembunyian nyamuk, seperti di bawah meja, kursi, tempat tidur, dan tempat potensial lainnya) dan di luar rumah (5 meter dari rumah). Ovitrap diperiksa apakah ada/tidaknya telur pada kertas saring setelah satu minggu. Jumlah pemasangan ovitrap pada setiap rumah adalah 2 buah dengan total sebanyak 230 buah di 115 rumah sesuai standar Kemenkes RI (2013). Pemilihan rumah berdasarkan tabel data kasus

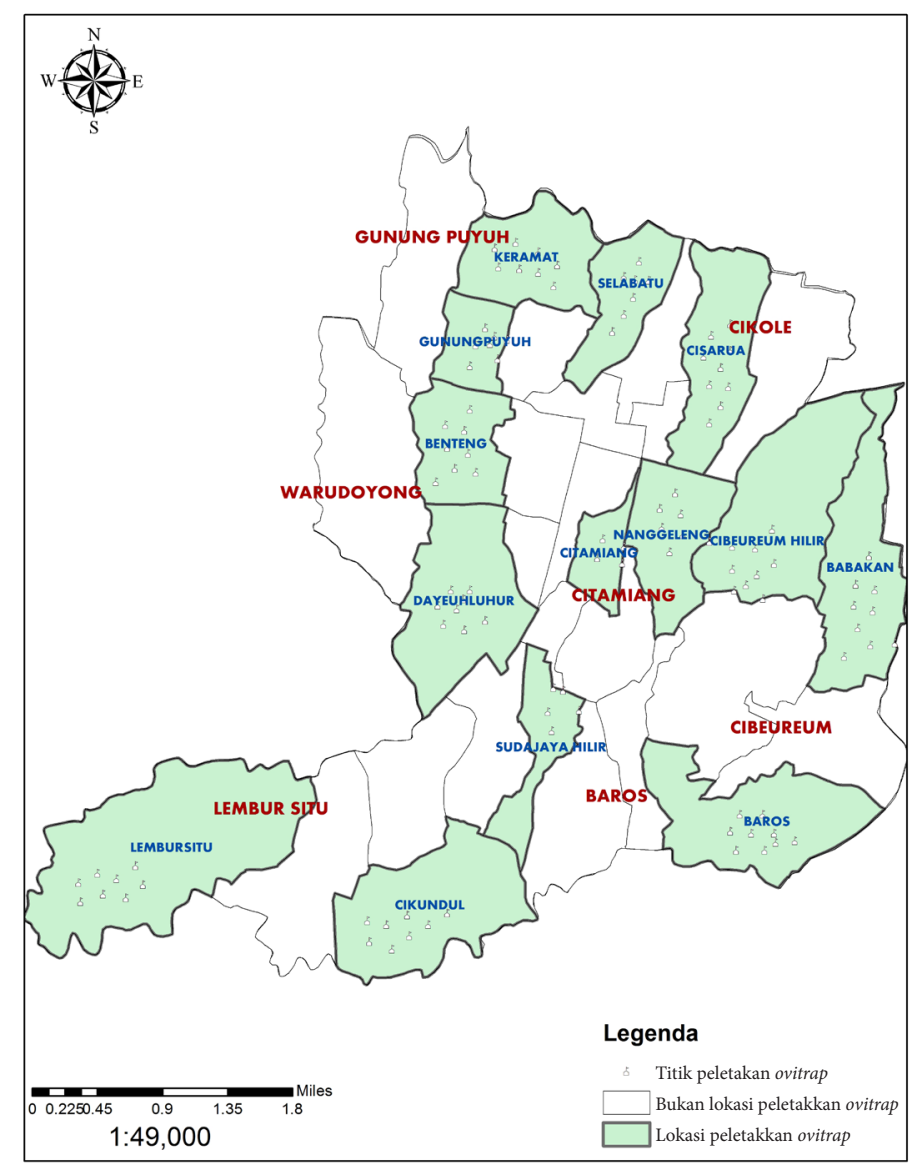

Gambar 1. lokasi pengumpulan telur Aedes spp di Kota Sukabumi, Indonesia. 
penderita DBD 6 bulan terakhir yang diperoleh dari petugas Pemberantas dan Pengendalian Penyakit di Dinas Kesehatan Kota Sukabumi. Selain itu, kondisi rumah penderita yang diletakan ovitrap juga diamati menggunakan tabel ceklist yang terdiri atas ketersediaan ventilasi udara, adanya genangan-genangan air di sekitar rumah, adanya gelas plastik, penampung air yang tidak tertutup yang merupakan indikator sanitasi jelek.

\section{Perkembangbiakan telur nyamuk}

Di Laboratorium Entomologi, Fakultas Kedokteran Hewan, Institut Pertanian Bogor, telur yang terperangkap pada kertas saring ovitrap di hitung menggunakan counter di bawah mikroskop. Penghitungan telur nyamuk dibedakan antara telur yang menempel pada kertas saring ovitrap di dalam dan di luar rumah pada masing-masing kelurahan. Telur yang telah dihitung dikumpulkan dan dimasukan ke dalam wadah yang diberi air sehingga telur yang kontak dengan air akan menetas menjadi larva dalam waktu 1-2 hari. Wadah penetasan nyamuk terdiri atas wadah yang berasal dari kertas saring ovitrap di dalam dan di luar rumah pada masing-masing kelurahan. Larva yang ada diidentifikasi dari bentuk sifonnya untuk membedakan genus Aedes, Culex, dan Anopheles. Ae. aegypti dan Ae. albopictus dibedakan dari bentuk comb. Kemudian, larva dipelihara dan diberi makanan rebusan hati ayam selama 6-8 hari sehingga akan menjadi pupa. Pupa ditempatkan tersendiri dalam wadah dan dipindahkan ke dalam kandang nyamuk. Biasanya dalam waktu 1-2 hari pupa tumbuh menjadi nyamuk dewasa. Kemudian, nyamuk dewasa diamati bentuk toraksnya untuk lebih memastikan spesies nyamuk yang diperoleh. Jika memiliki dua garis, seperti lyra merupakan $A$. aegypti dan jika memiliki garis putih tengah dari toraks sampai kepala merupakan A. albopictus.

\section{Analisis data}

Indeks ovitrap merupakan satu di antara ukuran yang menyatakan kepadatan telur nyamuk di suatu wilayah. Pengukuran indeks ovitrap dilakukan 1 minggu setelah pemasangan ovitrap dengan memeriksa keberadaan telur Aedes pada setiap ovitrap yang dipasang. Rumus ovitrap indeks sebagai berikut (FEDH 2014):

Ovitrap index $=\frac{\text { Jumlah kertas dengan telur }}{\text { Jumlah kertas diperiksa }} \times 100 \%$
Kriteria indeks ovitrap menurut FEDH, Hongkong dalam Fatmawati (2014) adalah level 1 : sangat rendah, dengan $\mathrm{OI}<5 \%$; level 2: rendah, dengan $5 \% \leq \mathrm{OI}<20 \%$; level 3 : sedang, dengan 20 $\leq \mathrm{OI}<40 \%$; dan level 4: tinggi, dengan OI $>40 \%$.

Analisis data menggunakan analisis bivariat untuk melihat hubungan kondisi rumah sampel dengan angka indeks ovitrap. Analisis data menggunakan uji Chi-square dan dianalisis dengan software SPSS 16.00. Uji statistik kemaknaan Chisquare digunakan untuk analisis bivariat variabel dependen kategorik dan variabel independen kategorik. Notoatmodjo (2010) menyatakan hasil analisis Chi-square dapat melihat perbedaan proporsi hubungan dari setiap variabel dengan kemaknaan hubungan pada derajat penolakan $\alpha=$ $5 \%(\mathrm{P}<0,05)$. Jika nilai $\mathrm{P}<0,05$ maka hipotesis nol ditolak sehingga dua variabel yang dianalisis memiliki hubungan yang bermakna. Analisis keeratan hubungan antara dua variabel tersebut, dilihat berdasarkan nilai odd ratio (OR). Besar kecilnya OR menunjukan besarnya keeratan hubungan antara 2 variabel yang di uji yang disajikan dalam tabel kontingensi $2 \times 2$.

\section{HASIL}

\section{Keanekaragaman nyamuk Aedes}

Hasil survei telur nyamuk diperoleh bahwa telur nyamuk hasil ovitrap menunjukan hanya ditemukan genus Aedes dan tidak dari telur genus lain. Nyamuk yang tertangkap pada ovitrap di dalam rumah merupakan Ae. aegypti dan nyamuk yang tertangkap di luar rumah merupakan $A e$. albopictus.

\section{Populasi Aedes sp. berdasarkan jumlah telur dan indeks ovitrap}

Ovitrap di dalam rumah yang positif mengandung telur nyamuk paling banyak ditemukan di Kelurahan Gunung Puyuh dan Keramat. Kedua kelurahan tersebut merupakan daerah dengan IR tertinggi di Kota Sukabumi pada tahun 2014. Sebaliknya, ovitrap yang mengandung telur nyamuk paling sedikit ditemukan di Kelurahan Baros dan Nanggeleng (Tabel 1).

Jumlah telur nyamuk dari ovitrap di dalam rumah sebanyak 1307 butir, sedangkan di luar rumah sebanyak 429 butir. Jumlah total telur 
nyamuk dari dalam rumah banyak ditemukan pada Kelurahan Keramat dan paling sedikit ditemukan pada Kelurahan Baros. Perolehan telur di luar rumah terbanyak pada Kelurahan Selabatu dan paling sedikit pada Kelurahan Babakan (Tabel 1). Perolehan telur Aedes sp. pada setiap ovitrap memperlihatkan bahwa Kelurahan Keramat masih menjadi kelurahan dengan jumlah telur/ovitrap terbanyak di Kota Sukabumi. Adapun Kelurahan Citamiang merupakan kelurahan yang paling sedikit ditemukan telur Aedes sp. pada setiap ovitrap-nya (Tabel 1).

Nilai OI yang ditemukan berkisar 25-68,75\% (Tabel 2). Aedes sp. banyak ditemukan karena pemukiman di Kota Sukabumi rapat, dan masih banyak ditemukan bak-bak penampungan air hujan. Indeks ovitrap mencapai $68,75 \%$ pada kelurahan Gunung Puyuh dan Cikundul (Tabel 2). Hal ini karena banyak ditemukan pemukiman yang rapat dikedua keluarahan tersebut dan masih

Tabel 1. Perolehan telur Aedes spp. di dalam dan diluar rumah di 14 kelurahan di Kota Sukabumi pada bulan Mei hingga Agustus 2015

\begin{tabular}{lllccccc}
\hline \multirow{2}{*}{ Kelurahan } & \multicolumn{2}{c}{ Ovitrap positif } & \multicolumn{2}{c}{ Jumlah telur total } & \multicolumn{2}{c}{ Jumlah telur/ovitrap positif } & Indeks ovitrap \\
\cline { 2 - 7 } & Dalam (\%) & Luar (\%) & Dalam & Luar & Dalam & Luar & $(\%)$ \\
\hline Selabatu & $4(50)$ & $6(75)$ & 146 & 84 & 36,5 & 14 & 62,5 \\
Gunung Puyuh & $8(100)$ & $3(37,5)$ & 113 & 35 & 14,13 & 11,67 & 68,75 \\
Cikundul & $5(62,5)$ & $6(75)$ & 86 & 74 & 17,2 & 12,33 & 68,75 \\
Sudajaya hilir & $3(37.5)$ & $1(12,5)$ & 56 & 10 & 18,67 & 10 & 25 \\
Benteng & $7(87,5)$ & $2(25)$ & 48 & 12 & 6,86 & 6 & 56,25 \\
Dayeuh Luhur & $3(37,5)$ & $5(62,5)$ & 29 & 36 & 9,67 & 7,2 & 50 \\
Cisarua & $8(88,89)$ & $2(22,22)$ & 157 & 42 & 19,63 & 21 & 55,56 \\
Babakan & $3(33,33)$ & $1(11,11)$ & 64 & 4 & 21,33 & 4 & 22,22 \\
Lembur Situ & $4(40)$ & $1(12,5)$ & 78 & 13 & 19,5 & 13 & 31,25 \\
Citamiang & $6(65)$ & $2(25)$ & 37 & 7 & 6,17 & 3,5 & 50 \\
Cibeureum Hilir & $6(6,67)$ & $4(44,44)$ & 94 & 22 & 15,67 & 5,5 & 55,56 \\
Keramat & $8(100)$ & $2(25)$ & 268 & 24 & 33,5 & 12 & 62,5 \\
Baros & $2(25)$ & $3(37,5)$ & 28 & 17 & 14 & 5,67 & 31,25 \\
Nanggeleng & $2(25)$ & $5(62,5)$ & 103 & 49 & 5,5 & 9,8 & 43,75 \\
\hline Total & $69(60)$ & $43(37,39)$ & 1307 & 429 & 18,94 & 9,98 & 48,7 \\
\hline
\end{tabular}

Tabel 2. Indeks ovitrap di dalam dan di luar rumah, 14 kelurahan, Kota Sukabumi tahun 2015 pada bulan Mei hingga Agustus 2015

\begin{tabular}{lcccc}
\hline \multirow{2}{*}{ Kelurahan } & \multirow{2}{*}{$\begin{array}{c}\text { Range rataan perolehan telur } \\
\text { di dalam dan luar rumah }\end{array}$} & $\begin{array}{c}\text { Indeks ovitrap dari masing-masing } \\
\text { kelurahan } 8 \text { ovitrap }(\%)\end{array}$ & $\begin{array}{c}\text { Total indeks ovitrap di } \\
\text { dalam dan luar rumah }\end{array}$ \\
\cline { 3 - 4 } & & Dalam rumah & Luar rumah & $(\%)$ \\
\hline Selabatu & $0-34,5$ & 50,00 & 75,00 & 62,5 \\
Gunung Puyuh & $0-27,5$ & 100,00 & 37,50 & 68,75 \\
Cikundul & $0-25$ & 62,50 & 75,00 & 68,75 \\
Sudajaya hilir & $0-14$ & 37,50 & 12,50 & 25 \\
Benteng & $0-10,5$ & 87,50 & 25,00 & 56,25 \\
Dayeuh Luhur & $0-7,5$ & 37,50 & 62,50 & 50 \\
Cisarua & $0-26,5$ & 88,89 & 22,22 & 55,56 \\
Babakan & $0-14,5$ & 33,33 & 11,11 & 22,22 \\
Lembur Situ & $0-19$ & 50,00 & 12,50 & 31,25 \\
Citamiang & $0-5,5$ & 75,00 & 25,00 & 50 \\
Cibeureum Hilir & $0-20,5$ & 66,67 & 44,44 & 55,56 \\
Keramat & $8-36,5$ & 100,00 & 25,00 & 62,5 \\
Baros & $0-7,5$ & 25,00 & 37,50 & 31,25 \\
Nanggeleng & $0-40,5$ & 25,00 & 62,50 & 43,75 \\
\hline Total & $22-146$ & 60,00 & 37,39 & 48,7 \\
\hline
\end{tabular}


banyak ditemukan bak-bak penampungan air hujan, berdasarkan pengamatan selama peletakan ovitrap Aedes sp.

Berdasarkan grafik dari perolehan total telur Aedes sp., dapat disimpulkan bahwa Kelurahan Keramat adalah kelurahan dengan perolehan total telur Aedes sp. di dalam rumah tertinggi dan sebaran telur Aedes sp. merata pada tiap rumah karena tidak ditemukan nilai outlier (Gambar 2A). Sebaliknya, Kelurahan Baros dan Dayeuh Luhur merupakan kelurahan terendah memperoleh telur Aedes sp. Perolehan telur Aedes sp. di luar rumah terbanyak ditemukan di Selabatu dan Cikundul dengan sebaran rata pada tiap rumahnya dan paling sedikit di Babakan. Perolehan telur Aedes sp di luar rumah pada Kelurahan Cisarua pada grafik menunjukan bahwa dari 9 rumah yang diletakan ovitrap hanya satu rumah, yaitu rumah ke- 8 yang ditemukan telur Aedes sp sebanyak 50-60 butir telur (Gambar 2B).

\section{Hubungan indeks ovitrap dengan kondisi rumah}

Hubungan indeks ovitrap dengan kondisi rumah disajikan dalam Tabel 3. Rumah dengan ventilasi dan sanitasi buruk memiliki hubungan yang signifikan terhadap angka indeks ovitrap $(\mathrm{P}=0,01, \mathrm{OR}=3,09$, Tabel 3). Berdasarkan nilai

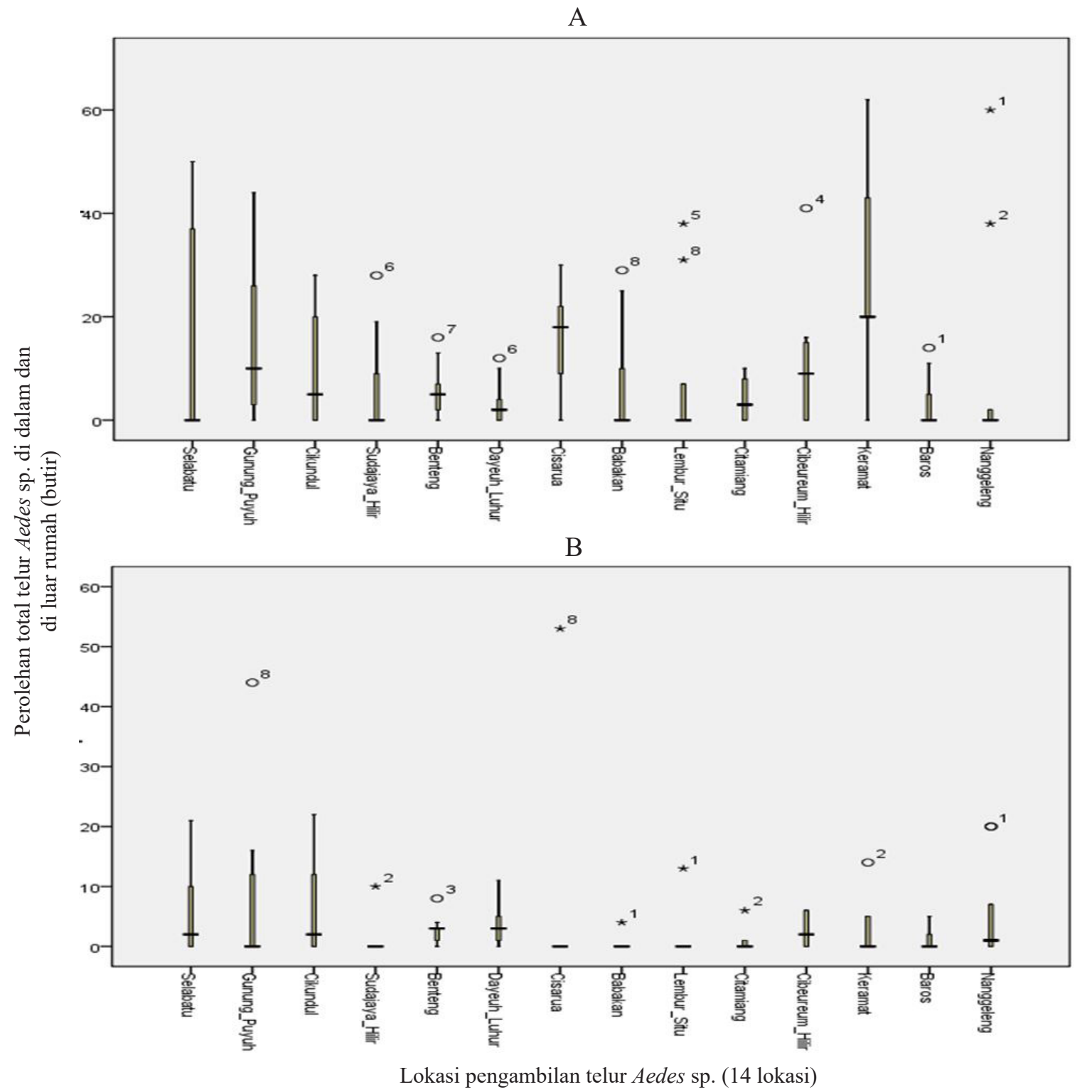

Gambar 2. Perolehan total telur Aedes sp. A: di dalam; dan B: di luar pada masing-masing rumah di Kota Sukabumi dengan * sebagai nilai ekstrim dan o sebagai outlier. Angka pada outlier dan nilai ekstrim menunjukan total telur Aedes sp. pada rumah ke-n. 
Tabel 3. Analisis bivariat kondisi rumah terhadap angka indeks ovitrap di Kota Sukabumi

\begin{tabular}{|c|c|c|c|c|c|c|c|}
\hline \multirow{2}{*}{ Variabel } & & \multirow{2}{*}{ Total rumah } & \multicolumn{2}{|c|}{ Indeks ovitrap } & \multirow{2}{*}{ p-value } & \multirow{2}{*}{ OR } & \multirow{2}{*}{$\mathrm{Cl} 95 \%$} \\
\hline & & & Tinggi & Sedang & & & \\
\hline \multirow{2}{*}{$\begin{array}{l}\text { Kondisi } \\
\text { Rumah }\end{array}$} & Sanitasi dan & 72 & $61(79,2 \%)$ & $16(20,8 \%)$ & & & \\
\hline & $\begin{array}{l}\text { ventilasi buruk } \\
\text { Sanitasi dan } \\
\text { ventilasi baik }\end{array}$ & 43 & $21(55,3 \%)$ & $17(44,7 \%)$ & $0,01 *$ & 3,09 & $1,33-7,18$ \\
\hline
\end{tabular}

*Hasil analisis Chi-square yang menunjukkan hubungan signifikan. OR: odds ratio; $\mathrm{Cl}$ : confident interval.

OR, rumah-rumah di Kota Sukabumi dengan kondisi ventilasi dan sanitasi buruk berisiko 3,09 kali meningkatkan kepadatan Aedes sp. (indeks ovitrap) dibandingkan dengan rumah dengan ventilasi dan sanitasi baik.

\section{PEMBAHASAN}

Survei nyamuk dengan menggunakan ovitrap lebih sensitif, ekonomis dan reliable untuk mendeteksi kepadatan nyamuk Ae. aegypti dan Ae. albopictus dibandingkan dengan survei larva pada kontainer. Rozilawati et al. (2015) melaporkan bahwa pemasangan ovitrap lebih berguna dan teknik yang akurat untuk memonitor dan mengamati Aedes sp. ketika survei larva menunjukan angka infestasi rendah.

Hasil survei telur menggunakan ovitrap di Kota Sukabumi diperoleh jumlah telur terbanyak ditemukan pada daerah endemisitas tinggi, yaitu Kelurahan Keramat. Wahyuningsih et al. (2009) melaporkan bahwa total telur di daerah dengan kasus DBD tinggi paling banyak dibandingkan dengan daerah dengan kasus DBD rendah. Sedangkan ovitrap yang ditempatkan di Kota Bandung diperoleh hasil bahwa Ae. aegypti ditemukan hampir di seluruh daerah peletakan ovitrap dan banyak ditemukan di luar dibandingkan dengan di dalam rumah (Syarifah et al. 2008). Hal ini sejalan dengan penelitian yang dilakukan oleh Wijayanti et al. (2017) yang menyatakan bahwa telur nyamuk banyak ditemukan di luar rumah dengan OI tertinggi di desa Kranji wilayah kerja Puskesmas Purwokerto Timur II. Norzahira et al. (2011) melaporkan bahwa terdapat 4 titik lokasi (Timur A, Barat B, Barat A, dan Timur B) di daerah Bentong, Pahang, Malaysia yang menjadi peletakan ovitrap dan kebanyakan $\mathrm{Ae}$. aegypti berada di dalam dan luar rumah dengan range indeks ovitrap sebesar $8-47 \%$ (Ae. aegypti) dan 37-78\% (Ae. albopictus). Ho et al. (2005) melaporkan bahwa di Taiwan pada tahun 2002, rata-rata indeks ovitrap yang diperoleh pada daerah Kaohsiung dan Tainan adalah $46 \%$. Spesies yang dominan ditemukan pada kedua daerah tersebut adalah Ae. aegypti pada tahun 2002. Rozilawati et al. (2015) melaporkan bahwa semua lokasi pemasangan ovitrap mengindikasikan bahwa $A e$. albopictus ditemukan lebih dominan di dalam rumah kecuali satu daerah (Sentul Untama Flat) ditemukan Ae. aegypti luar rumah, tetapi dalam jumlah sedikit dibandingkan dengan di dalam rumah. Rudnick (1986) di Malaysia melaporkan Ae. aegypti paling banyak ditemukan di dalam rumah, berkembangbiak di tempat penampungan air buatan, dan menggigit atau menghisap darah di dalam rumah, sedangkan Dhang et al. (2005) melaporkan bahwa Ae. aegypti ditemukan di dalam dan luar rumah di daerah perkotaan dan pinggiran hutan. Devi et al. (2013) memperoleh hasil bahwa angka indeks ovitrap di luar rumah paling tinggi dibandingkan dengan di dalam rumah berdasarkan surveilans ovitrap di Uttarakhand State, India dengan total keseluruhan spesies Aedes yang tertangkap adalah 6 (Ae. aegypti, Ae. albopictus, Ae edwardsi, Ae. pseudotaeniatus, Ae. unilineatus, dan Ae. vitattus).

Berdasarkan observasi selama penelitian ketika pemasangan ovitrap di Kota Sukabumi ditemukan bahwa Ae. aegypti merupakan nyamuk di permukiman karena stadium pradewasanya mempunyai habitat di tempat penampungan air/wadah yang berada di permukiman. Hal ini disebabkan spesies Aedes mempunyai sifat anthropofilik, artinya lebih memilih menghisap darah manusia dan juga bersifat multiple feeding, artinya menghisap darah beberapa kali untuk 
memenuhi kebutuhan darah sampai kenyang dalam satu periode siklus gonotropik (Sukowati 2010; Hadi \& Koesharto 2006).

Pada survei telur nyamuk juga dibuktikan bahwa kondisi rumah dengan ventilasi dan sanitasi buruk juga berpengaruh terhadap kepadatan nyamuk terutama Aedes sp. Dhang et al. (2005) menyatakan bahwa Aedes tidak hanya berhubungan dengan pemukiman yang kumuh, tetapi juga berhubungan dengan permukiman yang padat penduduk. Penelitian yang dilakukan oleh Harrington et al. (2005) di Thailand dan Puerto Rico menyimpulkan bahwa pemukiman penduduk yang padat dan berada di perkotaan serta kurangnya perhatian terhadap kebersihan lingkungan merupakan tempat yang berpotensi sebagai breeding place dari Aedes sp. Selain itu, adanya genangan air, tidak mengubur gelas plastik bekas dan tidak menutup penampungan air juga berpotensi sebagai perkembangbiakan nyamuk sehingga memungkinkan nyamuk terkonsentrasi pada lokasi tersebut (Sari 2005).

Pertumbuhan penduduk yang meningkat dan arus urbanisasi yang tidak terkendali menyebabkan banyak penduduk yang tinggal di suatu wilayah dengan standar rendah, transportasi yang baik, kurangnya kesadaran masyarakat terhadap kebersihan lingkungan yang semuanya menunjang bagi kehidupan Aedes dan mempermudah transmisi DBD di antara penduduk.

\section{KESIMPULAN}

Ae. aegypti ditemukan di dalam rumah dan Ae. albopictus di luar rumah. Jumlah telur yang diperoleh dari ovitrap di dalam rumah 3 kali lebih banyak dibandingkan dengan telur dari ovitrap di luar rumah di Kota Sukabumi (1307 banding 429). Indeks ovitrap di dalam rumah mencapai $60 \%$, atau 1,6 kali lebih banyak dibandingkan dengan indeks ovitrap di luar rumah (37\%) di 14 kelurahan di Kota Sukabumi. Kondisi rumah dengan ventilasi dan sanitasi buruk, berisiko 3,09 kali untuk meningkatkan angka indeks ovitrap (kepadatan Aedes sp. tinggi).

\section{UCAPAN TERIMA KASIH}

Penulis mengucapkan terima kasih kepada seluruh staff Divisi Parasitologi dan Entomologi Kesehatan atas ijin, bantuan, dan kerjasamanya selama pelaksanaan penelitian ini berlangsung dan semua pihak yang telah membantu sehingga penelitian ini dapat berjalan lancar.

\section{DAFTAR PUSTAKA}

Barrera R, Mackay AJ, Amador M. 2013. A novel autocidal ovitrap for the surveillance and control of Aedes aegypti. Journal of the American Mosquito Control Association 29:293-296. doi: https://doi.org/10.2987/13-6345R.1.

Beech CJ, Nagaraju J, Vasan SS, Rose RI, Othman RY, Pillai V, Saraswathy TS. 2009. Risk analysis of a hypothetical open field release of a self-limiting transgenic Aedes aegypti strain to combat dengue. Asia Pacific Journal of Molecular Biology and Biotechnology.

Christophers SR. 1960. Aedes aegypti (L) The Yellow Fever Mosquito. Its Life History, Bionomics and Structure. London (UK): Cambridge Univ Press.

Devi P, Jauhari RK, Mondal R. 2013. Ovitrap surveillance of Aedes mosquitoes (Diptera: Culicidae) in selected areas of Dehradun District, Uttarakhand, India. Global Journal of Medical Research Diseases 13:53-57.

de Resende MC, Silva IM, Ellis BR, Eiras AE. 2013. A comparison of larval, ovitrap and mosquito trap surveilance for Aedes (Stegomyia) aegypti. Memórias do Instituto Oswaldo Cruz 108:1024-1030. doi: https://doi.org/10.1590/00740276130128.

[Dinkes Provinsi Jawa Barat] Dinas Kesehatan Provinsi Jawa Barat. 2015. Laporan Tahunan Program Demam Berdarah. Sukabumi: Dinas Kesehatan Provinsi Jawa Barat.

Dhang CC, Benjamin S, Saranum MM, Fook CY, Lim LH, Ahmad NW, Sofian-Azirun M. 2005. Dengue vector surveillance in urban residential and settlement areas in Selangor, Malaysia. Tropical Biomedicine 22:39-43.

[DKK Sukabumi] Dinas Kesehatan Kota Sukabumi. 2015. Laporan Tahunan Program Demam Berdarah. Sukabumi: Dinas Kesehatan Kota Sukabumi.

[FEDH] Food and Environment Hygiene Department. 2014. Dengue fever ovitrap index 
update. Tersedia di: http://www.fehd.gov.hk/ english/safefood/dengue_fever/ovitrap_index. html [diakses 12 Januari 2017].

Gubler DJ. 1998. Dengue and dengue hemorrhagic fever. Clinical Microbiology 480-496.

Hadi UK, Koesharto FX. 2006. Nyamuk. In: Sigit HS, Hadi UK (Eds.), Hama Pemukiman Indonesia: Pengenalan, Biologi, dan Pengendalian. pp. 318-319. Bogor: Unit Kajian Pengendalian Hama Pemukiman Fakultas Kedokteran Hewan IPB.

Harrington LC, Scott TW, Lerdthusnee K, Coleman RC, Costero A, Clark GG, Jones JJ, Kitthawee S, Kittayapong P, Sithiprasasna R, Edman JD. 2005. Dispersal of the dengue vector Aedes aegypti within and between Rural Communities. American Journal of Tropical Medical Hygiene 72:209-222.

Ho CM, Lin MW, Hsu EL, Wu SC, Pai HH, Yin CM. 2005. Surveillance for dengue fever vectors using ovitraps at Kaohsiung and Tainan in Taiwan. Fermosan Entomology 25:159-174.

Mackay A, Amador M, Barrera R. 2013. An improved autocidal gravid ovitrap for control and surveilance of Aedes aegypti. Parasites \& Vectors 6:225. doi: https://doi.org/10.1186/17563305-6-225.

Mohiddin A, Jaal Z, Lasim AM, Dieng H, Zuharah WF. 2015. Assessing dengue outbreak areas using vektor surveillance in north east district, Penang Island, Malaysia. Asian Pasific Journal of Tropical Disease 5:869-879. doi: https://doi. org/10.1016/S2222-1808(15)60947-1.

Norzahira R, Hidayatulfathi O, Wong HM, Cheryl A, Firdaus R, Chew HS, Lim KW, Sing KW, Mahathavan M, Nazni WA, Lee HL, Vasan SS, McKemey A, Lacroix R. 2011. Ovitrap surveillance of the dengue vectors, Aedes (Stegomyia) aegypti (L.) and Aedes (Stegomyia) albopictus Skuse in Selected Area in Bentong, Pahang, Malaysia. Tropical Biomedicine 28:4854.

Notoadmodjo S. 2010. Metodologi Penelitian Kesehatan. Jakarta: Rineka Cipta.

Rozilawati H, Tanaselvi K, Nazni WA, Mohd Masri S, Zairi J, Adanan CR, Lee HI. 2015. Surveilance of Aedes albopictus Skuse breeding preference in selected dengue outbreak localities, Peninsular Malaysia. Tropical Biomedicine 32:49-64.
Rudnick A. 1986. Dengue fever epidemiology in Malaysia. In: Rudnick A, Lim TW, Ireland JL (Eds), Dengue Fever Studies in Malaysia. pp. 1901-1980. Malaysia: Institute for Medical Research.

Sari CIN. 2005. Pengaruh lingkungan terhadap Perkembangan Penyakit Malaria dan Demam Berdarah Dengue. Tersedia di: http://www. rudyct.com/PPS702-ipb/09145/cut-irsanya-ns. pdf [diakses 12 Januari 2017].

Sukowati S. 2010. Masalah vektor demam berdarah dengue (DBD) dan pengendalian di Indonesia. Buletin Jendela Epidemiologi 2:26-30.

Syarifah N, Rusmatini T, Tjahjono D, Huda F. 2008. Ovitrap ratio of Aedes aegypti larvae collected inside and outside houses in a community survey to prevent dengue outbreak, Bandung, Indonesia, 2007. Tropical Medicine Parasitology 3:116120.

Wahyuningsih NE, Rahardjo M, Hidayat T. 2009. Keefektifan penggunaan dua jenis ovitrap untuk pengambilan contoh telur Aedes sp. di lapangan. Jurnal Entomologi Indonesia 6:95-102. doi: https://doi.org/10.5994/jei.6.2.95.

Wan-Norafikah O, Nazni WA, Noramiza S, Shafa'ArKo'Ohar S, Heah SK, Nor-Azlina AH, KhairulAsuad M, Lee HI. 2011. Ovitrap surveillance and mixed infestation of Aedes aegypti (Linnaeus) and Aedes albopictus (Skuse) in Northern Region and Southern Region of Malaysia. Health and the Environment Journal 2:1-5.

Wan-Norafikah O, Nazni WA, Noramiza S, Shafa'Ar-Ko' Ohar S, Heah SK, Nor-Azlina AH, Khairul-Asuad M, Lee HI. 2012. Distribution of Aedes mosquitoes in three selected localities in Malaysia. Sains Malaysiana 41:1309-1313.

Wijayanti SPM, Anandari D, Maqfiroch AFA. 2017. Pengukuran indeks ovitrap (OI) sebagai gambaran kepadatan nyamuk di daerah endemis demam berdarah dengue (DBD) Kabupaten Banyumas. Jurnal Kesmas Indonesia 8:47-54. doi: https://doi.org/10.20884/1.ki.2017.9.01.228. 